\title{
EUROPEAN JOURNAL OF FAMILY BUSINESS
}

http://www.revistas.uma.es/index.php/ejfb

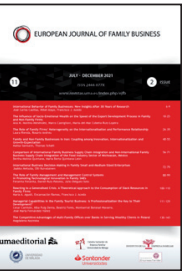

The Role of Family Firms' Heterogeneity on the Internationalisation and Performance Relationship

\author{
Laura Rienda $^{a *}$, Rosario Andreu ${ }^{\mathrm{a}}$ \\ a University of Alicante, Alicante, Spain \\ Research paper. Received: 2020-10-30; accepted: 2021-06-18
}

\section{JEL CLASSIFICATION Z320, M160, F230 \\ KEYWORDS \\ Family involvement, Heterogeneity, Performance, Internationalisation, Spanish hotel industry}

\section{CÓDIGOS JEL} Z320, M160, F230

\section{PALABRAS CLAVE} Implicación familiar, Heterogeneidad, Rendimiento, Internacionalización, Industria hotelera española

\begin{abstract}
Many papers have addressed the influence of different characteristics of family businesses on strategic decisions, including those of internationalisation. However, little is known about the relationship between the internationalisation of family firms and firm profitability. For this reason, from the socioemotional wealth perspective, in this paper, we focus on the moderating role of some heterogeneous characteristics of family firms on the relationship between internationalisation and business performance. Specifically, we analyse a sample of 76 companies belonging to the Spanish hotel industry, one of the most internationalised sectors and with a large presence of family businesses. The results show that family involvement in ownership and management, as well as generation, moderate the relationship between internationalisation and profitability in the Spanish hotel industry.
\end{abstract}

El papel de la heterogeneidad de las empresas familiares en la relación entre internacionalización y resultados

Resumen Muchos trabajos han abordado la influencia de las diferentes características de las empresas familiares en las decisiones estratégicas, incluidas las de internacionalización. Sin embargo, poco se sabe sobre la relación entre la internacionalización de las empresas familiares y la rentabilidad de la empresa. Por ello, desde la perspectiva de la riqueza socioemocional, en este trabajo nos centramos en el papel moderador de algunas características heterogéneas de las empresas familiares sobre la relación entre la internacionalización y los resultados empresariales. En concreto, analizamos una muestra de 76 empresas pertenecientes a la industria hotelera española, uno de los sectores más internacionalizados y con una gran presencia de empresas familiares. Los resultados muestran que la participación de la familia en la propiedad y la gestión, así como la generación, modera la relación entre la internacionalización y la rentabilidad en la industria hotelera española.

https://doi.org/10.24310/ejfbejfb.v11i2.10591

Copyright 2021: Laura Rienda, Rosario Andreu

European Journal of Family Business is an open access journal published in Malaga by UMA Editorial. ISSN 2444-8788 ISSN-e 2444-877X This work is licensed under a Creative Commons Atribution-NonCommercial-ShareAlike 4.0 International License (CC BY-NC-SA 4.0). 


\section{Introduction}

Nowadays, the internationalisation of family firms (FFs)' research continues studying the influence of distinctive aspects of the family on this strategy. Different theories try to explain the behaviour of FFs in order to balance the two more important issues in that companies: the family and the business. Emotional aspects can be against, or in the same sense, as the managerial and organizational aspects.

Some studies highlight that FFs link emotional and managerial aspects, and this link leads to the firm to take less risky decisions. Precisely, decisions related to the internationalisation process are considered as riskier because they could entail uncertainty to the managers (Gómez-Mejía et al., 2010; Kraus, 2016; Pukall \& Calabrò 2014). Internationalisation implies enter to a new market, usually with different rules, which in many cases is unknown, and which requires a significant investment. In FFs, the socioemotional-wealth (SEW) theory has studied this area of research and it points out that this kind of firms could be less internationalised.

Even though an increasing number of studies have dealt with different aspects of the internationalisation process in the context of FFs, such as their propensity to international growth (Calabrò et al., 2017; Pukall \& Calabró, 2014), the entry mode choice (Andreu et al., 2020; Boellis et al., 2016; Mariotti et al., 2021; Yamanoi \& Asaba, 2018), or the influence of firm's capabilities (Alayo et al., 2021; Hernández-Perlines, 2018), few studies have carried out an in-depth analysis of the relationship between international activity and performance considering different aspects of family involvement, being one of the main topics that needs a further attention (Kim \& Gao, 2013).

Therefore, more studies are needed on the relationship between internationalisation and performance in FFs. In this regard, we address this relationship in the case of the Spanish hotel sector. Within Spanish tourism, the hotel sector has achieved great importance worldwide. The Spanish hotel sector enjoys great recognition on the international scene (Martorell et al., 2016). In last decades, this sector has reached a high level of internationalisation by growing the number of hotels abroad (Andreu et al., 2020; Brida et al., 2015). In relation to the internationalisation strategy, one of the most researched topics has been the choice of entry mode, since this sector has certain peculiarities, such as the use of management contracts, franchising or leasing agreements (Contractor \& Kundu, 1998). Moreover, the Spanish hotel industry is characterized by a high percentage of FFs (Andreu, et al., 2018, 2020). However, little is known about the influence of family character on international strategies of these firms. The status of the Spanish hotel industry as one of the most globalised industries and with a high percentage of FFs, makes it interesting to focus our study in this sector.

For all that reasons, drawing on the SEW perspective, we investigate whether the characteristics of FFs affect the internationalisation-performance relationship of Spanish hotel chains. The SEW perspective helps us to know why FFs accept more or less risk in their international decisions. Risk and international decisions are linked with the need of these FFs to obtain long-term benefits. More precisely, we try to analyse the influence of certain family factors as moderating variables of the degree of internationalisation and performance relationship of family hotels. This analysis allows us to evaluate the impact of different characteristics associated to FFs involvement on internationalisation, and to underline the importance of considering the heterogeneity in $\mathrm{FF}$ research.

This study aims to contribute to our understanding of the internationalisation-performance relationship and how family involvement influences it. First, we have explored the influence of the family characteristics on internationalisation-performance relationship. Second, we have examined FFs in an under-research context. One possible explanation of different results in FF research could be related with the industry. The vast majority of the studies are focused on manufacturing sector, and further research is needed in other contexts. Third, we have enlarged the papers focus on the SEW theory, including a sample of hotels based in Spain, and corroborating the ideas of this perspective in the service sector.

The paper is structured as follows. The next section includes a revision of different studies on internationalisation-performance relationship focusing on the hotel industry, including several hypotheses related to the internationalisation-performance relationship and the moderating effect of family involvement. Later, the methodology section describes the sample and the variables included in our study. Subsequently, the results section shows the main results and the confirmation of the previous developed hypotheses. The paper continues with a discussion, conclusions and future research section, which explains the relations we found linking with the SEW premises.

\section{Literature Review}

2.1. Internationalisation, hotel chain performance and family involvement

Despite the costs associated with internationalisation, related to the need to handle possi- 
ble cultural differences (Hofstede, 1980) which increase the risks and costs involved in undertaking or making progress in this type of corporate strategy (Ruigrok \& Wagner, 2003), there are actually many benefits to becoming internationalised. A number of theories postulate advantages derived from the chance to obtain economies, and reduced costs, as a result of being positioned in various markets (Buckley \& Casson, 1976; Caves, 1971). Others refer to possible advantages concerning risk diversification (Elango, 2004; Levy \& Sarnat, 1970). And, from a perspective closer to management, internationalisation is associated with the increase or creation of specific competences resulting from the transfer of resources between different international units. The resource-based view and the theory of organisational learning propose the consideration of global resources and basic skills as drivers of organisational learning and knowledge development inside enterprises (Wernerfelt, 1984). These theories might explain the real impact of internationalisation on performance (Ruigrok \& Wagner 2003). International expansion can be considered a learning process that provides opportunities to access to new resources (Casillas et al., 2009; Luo, 2002). Companies are collections of knowledge and their learning capacity determines their growth strategies and their possibility of achieve a sustainable competitive advantage.

In relation to FFs, Alayo et al. (2021) found that innovation provides important resources and capabilities to international strategies. The internationalisation of FFs offers potential benefits as access to new markets and resources, cost saving opportunities, risk diversification, therefore expecting a positive effect of internationalisation on performance (Debicki et al., 2020; Graves \& Shan, 2014; Lu et al., 2015; Tsao \& Lien, 2013). As Debicki, et al. (2020) point out from the SEW perspective, FFs can internationalise to preserve their socioemotional goals, for example, by giving a family member a position of responsibility related to international operations, capitalizing on family social ties, and increasing their commitment and attachment to the firm.

In the specific case of the hotel sector, different studies found a significant positive relationship for the hotel industry, insofar as performance improves with the degree of internationalisation (Brida et al., 2016; Lee et al., 2014). In the FFs context, recent research reveals that family hotels improve the performance when there is a greater degree of internationalisation and the number of hotels and rooms they have abroad increases (Lee et al., 2014; Rienda et al., 2020). According the above arguments, a positive relationship between the internationalisation and performance can be expected, as we proposed in the following hypothesis:

Hypothesis 1: There is a positive relationship between the degree of internationalisation and performance in hotel chains.

However, different studies point out that the link between internationalisation and performance is more complex and other variables related to the heterogeneity of familiness need to be considered as they can moderate this relationship (Assaf et al., 2016; Debicki et al., 2020; Lu et al., 2015; Stieg et al., 2018).

\subsection{Family involvement as a moderating variable in internationalisation-performance relationship}

The SEW perspective is one of the main theoretical approaches in the FF field and helps to explain the distinctive behaviour of some FFs. This perspective suggests that family owners take advantages from the socio-emotional aspects of the business (Gómez-Mejía et al., 2011). In this context, the FF usually chooses strategies that fulfil its motivations to preserve and enhance the SEW (Liang et al., 2014). Nowadays, the SEW approach is a dominant perspective in FF research. However, the influence of SEW on long-term decisions seems to be inconsistent (Chiu, 2015; Strike et al., 2015). Hence, a more in-depth analysis about SEW's propositions becomes necessary to explain FF behaviour (Kraus et al., 2016).

International decisions create uncertainty for both FFs and non-family firms (NFFs) (Mensching et al., 2016). Most studies consider that FFs try to preserve family SEW by avoiding risky international strategies (Gómez-Mejia et al., 2010; Kraus et al., 2016; Pukall \& Calabrò, 2014). These past studies focus only on the aware of potential SEW losses for FFs. Following this approach, FFs tend to be less favourably disposed than NFFs toward risky strategies when going abroad (Ray et al., 2018). Nevertheless, family involvement influences risk preferences and long-term orientation, thus affecting international strategies in different ways (Liang et al., 2014).

The influence of family involvement on internationalisation has been widely studied, finding different results (Arregle et al., 2017; Pukall \& Calabrò, 2014). On the one hand, we found studies that emphasize the aversion to risk of FFs and how this aversion could hamper international activity of these businesses, which tend to concentrate on local or regional markets (De Massis et al., 2016; Graves \& Thomas, 2006). On the other hand, other authors stress the positive attributes of FFs and how they can positively affect inter- 
nationalisation process (Carr \& Bateman, 2009; Zahra, 2003). In addition, some academics find no differences between FFs and NFFs regarding their internationalisation process (Cerrato \& Piva, 2012; Claver et al., 2007).

Similarly, with regard to the link between FF status and firm performance, the existing studies are far from conclusive. On the one hand, some authors stress that these enterprises characteristically reveal greater affinity of their ownersmanagers with the firm's mission; they prioritise the continuity of the business in the future and pay considerable attention to the relationships existing inside the firm (Davis et al., 2000). In turn, such an attitude is likely to help generate distinctive capabilities and to produce a better financial performance in the long run (Anderson \& Reeb, 2003; Miller \& Le Breton-Miller, 2006). On the other hand, we can find the opposite relationship with the characteristics of FFs being negatively associated with results (Filatochev et al., 2005; Westhead \& Howorth, 2006). From this perspective, stronger commitment or the need to perpetuate the business over time makes them more risk averse and leads them to adopt decisions that may prove detrimental to performance. Some studies even insist on the absence of a direct connection between a higher level of family involvement and performance (Kim \& Gao, 2013; Villalonga \& Amit, 2006).

One of the reasons for this lack of conclusive results are the different definitions of FFs considered (Abdellatif et al., 2010; Andreu et al., 2020; Arregle et al., 2017; Casillas \& Acedo, 2005; Kraus et al., 2016). In any case, there is a consensus to identify these companies when family members own a majority of shares, are involved in management, are present in the board of directors and wish to transmit the firm to subsequent generations (Mazzi, 2011). Family involvement brings a new point of view about the definition of FFs. Multiples studies focus on determine if a firm is familiar or not, but it is more interesting to analyse the degree of familiness showing the heterogeneity in FFs. Familiness is considered as the identification of "resources and capabilities that are unique to the family's involvement and interactions in the business" (Pearson et al., 2008). Considering different aspects related to the family in business may contribute to a better understanding of the FFs' characteristics (Alayo et al., 2019; Chua et al., 2012). As Sciascia et (2012) highlight, only a few studies distinguished the effects of family ownership from those of family involvement.

According to Ray et al. (2018), the most recognized sources of heterogeneity among FFs are family ownership and family involvement in management. When family possesses a great percent- age of firm ownership, following the SEW perspective, the need for control increases and it implies that internationalisation process could be affected. Family usually tries to reduce the risk associated to internationalisation strategy and the consequences of this risk-averse behaviour could negatively influence on the internationalisation strategy (Fernández \& Nieto, 2006; Ray et al., 2018) and, therefore, on firm's performance. Debicki et al. (2020) argue that family ownership has a negative moderating effect on the internationalisation-performance relationship. In their study, the relationship between international expansion and performance was weaker in firms with higher family ownership.

For the hotel industry, previous studies have shown the existence of a relationship between family ownership, internationalisation and performance in FFs (Rienda et al., 2020, 2021) being the role played by family owners essential (Xiao et al., 2012). So, according to these arguments based on SEW perspective, we propose the following hypothesis:

Hypothesis 2: The family ownership negatively moderates the degree of internationalisationperformance relationship in hotel chains.

The SEW also justifies the behaviour of FFs through the presence of family members on top management teams. When family members are involved in management, decisions related to the internationalisation are taken cautiously (Zahra, 2003). The individuals may seek maximizing revenues from foreign markets rather than aggressively pursuing internationalisation (Abdellatif et al., 2010). Managers tend to invest most of their wealth in the firm and, consequently, their decisions should be more riskaverse (Cerrato \& Piva, 2012), affecting the internationalisation process. When there is a high ratio of family members on top management positions, the firm has less diversity of skills and knowledge to undertake international strategies and negatively affect the internationalisation of the FFs (Alayo et al., 2019). Family-managed firms internationalise less than NFFs (Ray et al., 2018). External managers may have the necessary talent to expand into new countries. Besides, non-family managers can enhance the legitimacy of the firm, may be considered a sign of professionalism of the management and, consequently, could affect the performance achieved by the firm. Therefore, it is expected that FFs with a high percentage of family managers will negatively moderate the relationship between internationalisation and firm performance (Lu et al., 2015), as we propose in the following hypothesis: 
Hypothesis 3: The family management negatively moderates the internationalisation-performance relationship in hotel chains.

Finally, we consider the generation as another heterogeneity factor of FFs that may act as a key moderating variable to influence profitability (Sciacia et al., 2014). With respect to the generation which run the firm, several studies found that founder or first generations outperform better and later generations are associated with a decrease in performance (Miller et al., 2011; Morck et al., 2000; Villalonga \& Amit, 2006), although the opposite relationship also exists (Sraer \& Thesmar, 2007).

For internationalisation strategy, the results about the influence on the generation ruling the firm are also inconclusive (Mariotti et al., 2021) and more research is necessary to understand the relationship between the generation and international decisions (Segaro et al., 2014). Following the SEW perspective, in FFs governed by the founder, i.e., first generation FFs, the SEW orientation is dominant (Le-Breton Miller \& Miller, 2013). In more advanced generations the interests are less concentrated, and managers take lesser conservative decisions. New ideas coming from these generations changing the trend followed by founders (Pongelli et al., 2016). With the new generations, organizational capabilities increase in terms of variety, becoming more suitable to be exploited in different international contexts (Mariotti et al., 2021). As Sciacia et al. (2014) appointed, the emotional attachment of family members is likely to decrease at later generational stages. Therefore, SEW preservation is expected to be a less relevant goal than economic profitability in subsequent generations. According to these ideas, advanced generations may have more propensity to undertake riskier strategies as internationalisation in order to achieve a higher financial wealth. Consequently, a positive effect is expected between the advanced generations of the FFs and the internationalisationperformance relationship, as we propose in the last hypothesis:

Hypothesis 4: An advanced family generation positively moderates the internationalisationperformance relationship in hotel chains.

The proposed model is shown in figure 1.

\section{Methodology}

\subsection{Sample}

The sample was collected from the Alimarket Hotel and Catering Yearbook for the year 2016. Database contains financial and commercial data of the most important hotel chains with Spanish based headquarters (including both national chains and international groups). From a total of a 697 hotel chains, we selected only internationalised chains, i.e., those that had at least a hotel outside Spain, whether under property, management contract, leasing or franchised. 76 internationalised chains were identified, with a total of 2,378 hotels, 981 of which are located abroad (beyond Spain's borders). Moreover, $60.83 \%$ of these 76 internationalised hotel chains have family characteristics with different degrees of family involvement. Table 1 reports a description of the sample.

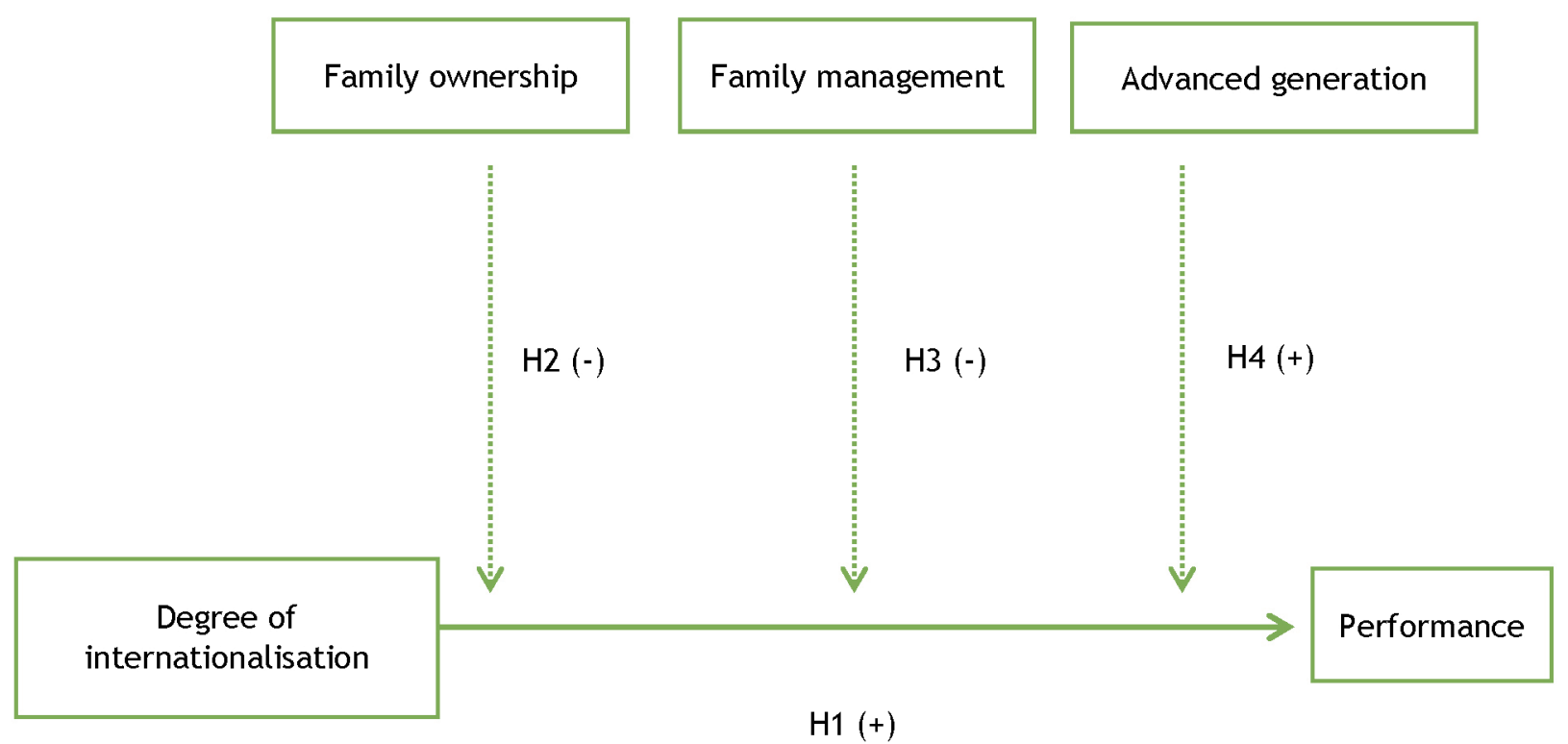

Figure 1. Model research 
Table 1. Sample description

\begin{tabular}{ll} 
Variables & \\
\hline Degree of internationalisation (mean) & $58.62 \%$ rooms abroad about total room \\
Family ownership (mean) & $47.29 \%$ of capital in family hands \\
Family management (mean) & $18.71 \%$ of family directives \\
Generation & $25.7 \%$ First generation (founder) firms \\
Firm size (mean) & $74.3 \%$ Advanced generation \\
Firm age (mean) & 3,101 number of employees \\
Performance (mean) & 26.47 number of years of the chain \\
\hline
\end{tabular}

\subsection{Measures}

Firm performance has been examined from different perspectives and contexts. In our case, performance was measured through the Revenue Per Available Room (RevPAR), a specific performance variable for the hotel industry (Namasivayam et al., 2007; Sainaghi, 2011; Schwartz et al., 2017). This variable was calculated by dividing the hotel's total guestroom revenue by the number of available rooms and the number of days during the measured period. We opted for the logarithm in order to normalise the values.

Regarding the degree of internationalisation (DOI), the ratio of sales abroad over total sales is often used (Grant et al., 1988; Miller et al., 2008). In the case of hotel industry, the most frequently used ratio is the number of rooms abroad over the total number of rooms (Lee et al., 2014). This variable shows us that the higher the ratio, the higher the degree. It has been used in previous studies on internationalisation in this industry (Brida et al., 2016; Lu \& Beamish, 2004; Ramón, 2002; Tallman \& Li, 1996).

One definition of family business basically considers that the majority of ownership and management of the firm should be in family hands as a requirement to categorize it (Claver et al., 2009; Graves \& Thomas, 2004). Nevertheless, the classification between FF and non-FF could be more detailed when we include different situations that show the heterogeneity of FFs. Family involvement in our study collects three related variables:

- Family ownership, measured with the percentage of the firm's equity held by the family. This measure was also used in previous studies (Astrachan \& Kolenko, 1994; Sciascia et al., 2012).

- Family management, measured with the percentage of family member in management positions. Family involvement increases when managerial position is occupied by a family member. The influence exerted by these own- ers who simultaneously hold top management positions enjoy the discretion of acting with the possibility to influence corporate decisions (Miller \& Le Breton-Miller, 2006). The percentage also indicates to what extent the firm uses managers outside the family. Other FFs research also included this variable in their studies (Cerrato \& Piva, 2012; Chua et al., 1999).

- Generation, which was collected through the information of different databases and consulting the corporate websites of those hotel chains with some degree of family involvement. Some previous studies analysed the influence of generation on the FFs' internationalisation. More precisely its impact on international commitment (Claver et al., 2009; Fernández \& Nieto, 2005) and other decisions such as entry mode abroad (Andreu et al., 2020; Claver et al., 2008). The FF literature suggests a variety of differences between first-generation FFs and later-generation FFs (Aronoff, 1998; Sonfield \& Lussier, 2004; Westhead et al., 2002). Following the study of Beck et al. (2011), we introduced a dummy variable which take the value 0 , for founder or first-generation FFs, and the value of 1 , for later or advanced generations. A greater family involvement is related with the first generations of FFs.

Finally, our study included some control variables. Firms may adopt different patterns of internationalisation based on their financial and managerial resource limitations (Brida et al., 2015). Hence, we controlled for firm size using the average employees of each hotel chain in the last three years, with a logarithmic transformation to normalise the variable distribution (García de Soto \& Vargas, 2015; Pla Barber \& León Darder, 2004).

We also included the firm age of the hotel chain. Firm age has been included in different studies to their possible influence on performance (Cuc- 
culelli et al., 2014). Moreover, older firms are expected to be more conservative in their strategic orientations (Zahra et al., 2008).

The category of hotels abroad was determined by means of a categorical variable according to the number of stars that each hotel has (between 1 and 5). This variable has already been used in several studies to assess the importance of a hotel's intangible assets understanding that, the higher the level of importance, the more control the firm will want to exert over it, which in turn can influence entry mode abroad (León-Darder et al., 2011; Plá et al., 2011).

\section{Results}

A correlation analysis is presented in Table 2, together with the multicollinearity analysis (VIF). In Table 3 is showed the linear regressions results including different models.
As we can see in the last table, model 3 and model 7 show a positive relationship between the DOI of Spanish hotel chains and performance, in line with hypothesis 1 . In the model 4 and model 7 , with respect to our hypothesis 2 , the results show a negative moderating effect of family ownership on the internationalisation-performance relationship, as we proposed according to the SEW theory. This result allows us to confirm the hypothesis 2 of our model.

Model 5 is related to our hypotheses 3 . We can observe that the moderating effect of family management on $\mathrm{DOI}$ is negative for performance. Nevertheless, if we observe the final model (model 7), we found a non-significant moderating effect when all relationships are included. Therefore, our hypothesis 3 is partially confirmed.

Finally, in relation to the generation that runs the firm (model 6 and model 7), we proposed that advanced family generation positively moderates

Table 2. Descriptive statistics and correlations

\begin{tabular}{|c|c|c|c|c|c|c|c|c|}
\hline & VIF & (1) & $(2)$ & (3) & (4) & (5) & (6) & (7) \\
\hline (1) Performance & - & & & & & & & \\
\hline (2) DOI & 1.49 & $0.232^{* *}$ & & & & & & \\
\hline (3) Family ownership & 2.12 & $0.291^{* *}$ & $-0.154^{* *}$ & & & & & \\
\hline (4) Family management & 3.11 & $0.156^{* *}$ & $-0.281^{* *}$ & $0.581^{* *}$ & & & & \\
\hline (5) Advanced generation & 2.29 & $-0.081^{*}$ & $0.415^{* *}$ & $-0.292^{* *}$ & $-0.661^{* *}$ & & & \\
\hline (6) Firm size & 2.41 & $0.532^{* *}$ & $0.351^{* *}$ & $0.204^{* *}$ & $-0.188^{* *}$ & $0.161^{* *}$ & & \\
\hline (7) Firm age & 2.85 & $0.318^{* *}$ & $0.311^{* *}$ & $0.161^{* *}$ & $-0.331^{* *}$ & $0.373^{* *}$ & $0.701^{* *}$ & \\
\hline (8) Hotel category & 1.13 & $0.251^{* *}$ & $0.224^{* *}$ & $0.201^{* *}$ & $0.100^{* *}$ & 0.053 & $0.181^{* *}$ & $0.156^{* *}$ \\
\hline
\end{tabular}

*Correlation is significant at the 0.05 level (2-tailed); ${ }^{* *}$ Correlation is significant at the 0.01 level (2-tailed)

Table 3. Results of linear regressions for internationalisation-performance relationship

\begin{tabular}{|c|c|c|c|c|c|c|c|}
\hline Variables & Model 1 & Model 2 & Model 3 & Model 4 & Model 5 & Model 6 & Model 7 \\
\hline \multicolumn{8}{|l|}{ Control variables } \\
\hline Firm size & $0.161^{* * *}$ & $0.159^{* * *}$ & $0.140^{* * *}$ & $0.136^{* * *}$ & $0.139^{* * *}$ & $0.135^{* * *}$ & $0.131^{* * *}$ \\
\hline Firm age & $-0.002 * * *$ & $-0.002^{* * *}$ & $-0.001 \dagger$ & -0.001 & -0.001 & -0.001 & 0.000 \\
\hline Hotel category & $0.042^{* * *}$ & $0.041^{* * *}$ & $0.027^{* * *}$ & $0.026^{* * *}$ & $0.027^{* * *}$ & $0.028^{* *}$ & $0.027^{* * *}$ \\
\hline \multicolumn{8}{|l|}{ Independent variables } \\
\hline DOI & & 0.001 & $0.001^{* * *}$ & $0.001^{* *}$ & $0.001^{* * *}$ & $0.006^{* *}$ & $0.006^{* *}$ \\
\hline Family ownership & & & $0.016^{*}$ & $0.095^{* * *}$ & $0.015^{*}$ & $0.017^{* *}$ & $0.109^{* * *}$ \\
\hline Family management & & & $0.031^{* * *}$ & $0.032^{* * *}$ & $0.089^{*}$ & $0.025^{* *}$ & $0.002^{*}$ \\
\hline Advanced generation & & & -0.041 & 0.000 & 0.020 & 0.107 & $0.127^{*}$ \\
\hline \multicolumn{8}{|l|}{ Moderator variables } \\
\hline DOI x family ownership & & & & $-0.001^{* * *}$ & & & $-0.001^{* * *}$ \\
\hline DOI x family management & & & & & $-0.001^{* *}$ & & 0.001 \\
\hline DOI $x$ advanced generation & & & & & & $-0.005^{* *}$ & $-0.005^{* *}$ \\
\hline Adjusted $R^{2}$ & 0.322 & 0.322 & 0.373 & 0.386 & 0.378 & 0.376 & 0.388 \\
\hline $\mathrm{F}$ & $154.022^{* * *}$ & $115.669^{* * *}$ & $83.283^{* * *}$ & $76.932^{* * *}$ & $74.609^{* * *}$ & $73.963^{* * *}$ & $62.301^{* * *}$ \\
\hline $\mathrm{N}=76$ & & & & & & & \\
\hline
\end{tabular}


the internationalisation-performance relationship in family hotels. However, in our models this variable negatively moderates the relationship raised in the paper. Therefore, the hypothesis 4 is not confirmed.

In order to illustrate all these moderating effects, we have included the following figure that allow us to better interpret the results obtained.
The graphs show that all considered characteristics of the familiness of Spanish hotel companies, negatively moderates the relationship between internationalisation and profitability. With regard to the control variables, firm size, age of the hotel chain and category of the hotels open abroad, the most of them have turned out to be significantly related to business performance.
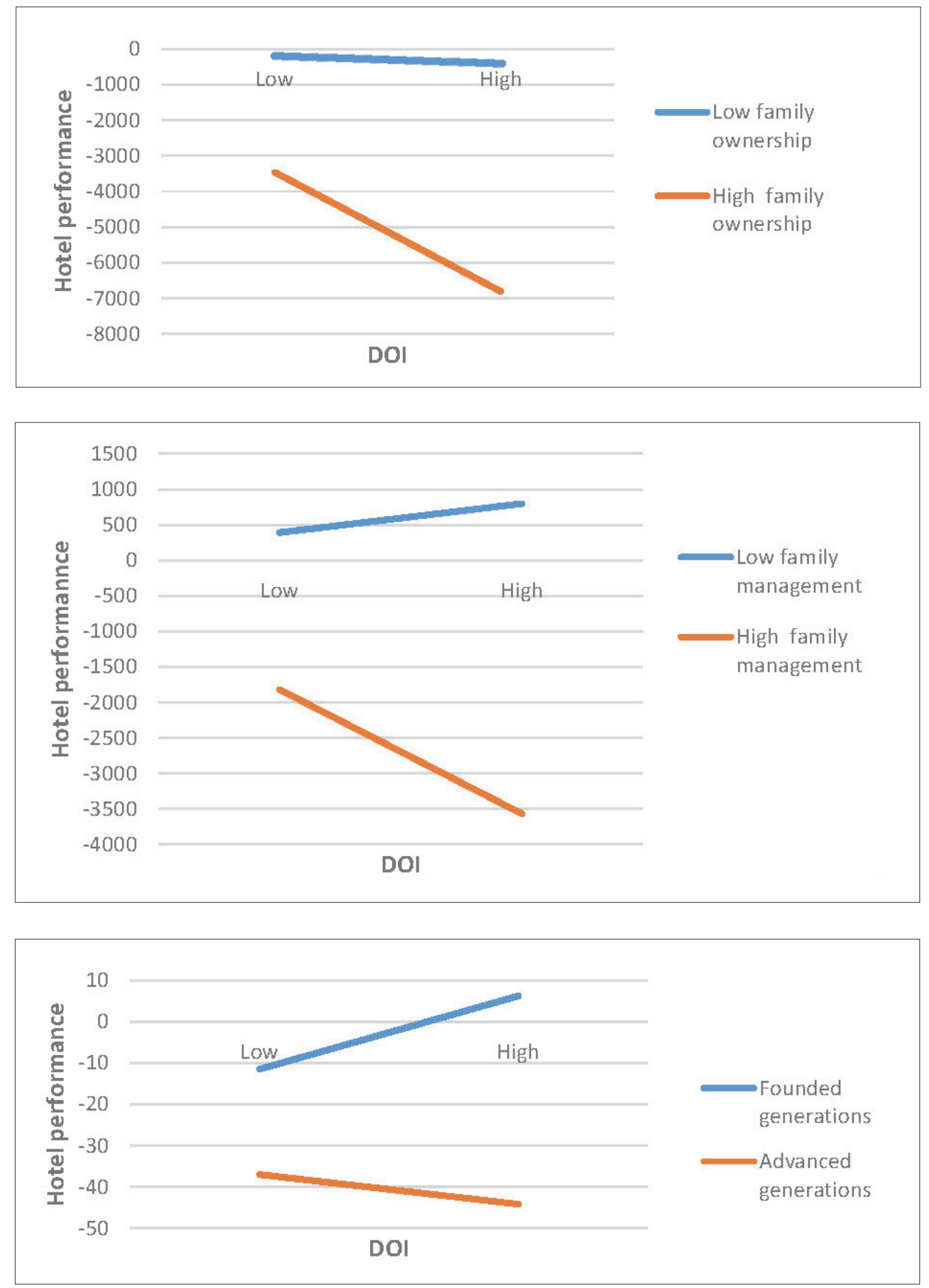

Figure 2. Moderating effect of family involvement on internationalisation-performance relationship 


\subsection{Robustness check}

We carried out several robustness checks in order to verify the evidence that the coefficients are robust (Lu \& White, 2014). To check the robustness of the model, we consider various alternatives. First, we change the dependent variable of our model and consider the EBITDA (Earnings Before Interest Taxes Depreciation and Amortization) as new performance measure (Anderson \& Reeb, 2003; Chrisman et al., 2004; Granata \& Chirico, 2010). With this dependent variable, we run the regression analysis and the results were consistent with those reported in Table 3. Second, we excluded, the firm that accumulates the largest number of investments covered by our sample. After removing this company, we performed the regression analysis and the results support our fourth hypotheses with similar levels of statistical significance.

\section{Discussion, Conclusions and Future Research}

Following the SEW theory, FFs may be risk-averse in order to protect the family wealth (Miller et al., 2010). Owners evaluate strategic decisions based on risks against financial returns, avoiding risks in order to preserve the family's SEW (Gómez-Mejía et al., 2010). The reason is that "family principals prefer to avoid risk because the costs of negative outcomes more than outweigh any benefits that might accrue through the pursuit of a high-risk/high-return strategy" (Gómez-Mejia et al., 2011, p. 665). Families act to preserve the business and, for this reason, they may become significantly risk-averse (Faccio et al., 2011). FFs have less incentive to undertake large-scale investments in distant countries due to worries about managerial control (Chen et al., 2009). However, recent studies have shown the positive benefits that FFs may gain by the internationalisation (Boellis et al., 2016; Löhde \& Calabró, 2019).

The results obtained in our study support the ideas of the SEW perspective attending to family ownership, that is to say, the firm acts in the market with the aim of preserving SEW, and FFs should prioritise family wealth over financial or economic profit (Zellweger et al., 2012). Family members are preoccupied with assuring the continuity of the business and the benefit of future generations (Miller et al., 2008). Considering that family ownership should be more risk-averse, the decisions related to internationalisation should also be affected and, hence, the firm performance. In our paper, the family ownership impact negatively to the relationship between internationalisation and performance, similarly to the studies of Debicki et al. (2020) or Lu et al. (2015).
In the same way we expected, family management negatively moderates the performance obtained with internationalisation. Nevertheless, the general model presents a non-significant moderating effect attending to the last variable. Other measures related to family management could be included to analyse this relationship in more detail. For example, the presence of a family CEO could be another important factor in international decisions. Family CEO can facilitate the alignment of interests between ownership and management. Besides, a family CEO may provide a better internal control mechanism and a better access to resources (Peng \& Jiang, 2010). Therefore, if family CEO shows a long-term orientation for firm's survival, the level of internationalisation would be positively influenced (Zahra, 2005) since growing across borders helps to strengthen the business in the long-run (Pukall \& Calabrò, 2014). A specific analysis of the characteristics of CEO could add more important information on the influence of he/she in strategic decisions of family hotels. Moreover, in the case of hotel industry, there are different entry modes that allow the firm entry to different markets without an important risk (Rienda et al., 2021). This is the case of the entry modes named "assets lights", which include management contracts and franchises. This specific decision concerning the internationalisation, not much investigated, could be a future line of research.

Contrary to what we expected, advanced generations moderate also negatively the internationalisation-performance relationship. Although new generations could be associated with a higher degree of internationalisation and new ideas (Pongelli et al., 2016), a great divergence of interest, due to the greater number of family members incorporated in the firm over time, could negatively affect this strategy and its effect on the FFs' performance. This relationship may be argued from the stewardship theory. This approach considers that the family increases in complexity with successive generations, and firm managers will perceive more risk from the search for market information, customer needs, or the firm's internal relations, increasing market threats and reducing the exploitation of market opportunities (Bobillo et al., 2013). More studies and different measures about the role of the generation are needed. In this regard, Mariotti et al. (2021) differentiated between the second generation and the first and third-and beyond generations. Miller et al. (2011) simultaneously considered whether the founder was the largest shareholder and serve as CEO of the company. There are also studies that analyse the influence of the founder on performance (Morck et al., 2000; Villalonga \& Amit, 2006) or the impact 
of family generation on different firm's decisions at international scene as entry mode (Mariotti et al., 2021), which raises future research topics. Two main contributions arise from this paper. First, from a SEW theory, our results contribute to reinforce the role of family involvement on firm's strategic decisions and the influence on firm performance. We can conclude that for Spanish hotel chains, family involvement differently moderates international-performance relationship. It is interesting to analyse the different aspects that are included in family involvement to a better understanding the results associated with some corporate strategies such as internationalisation. Second, this study helps to explain how family involvement affects internationalisation and hence contributes to FFs and internationalisation literature, particularly to hotel industry. We have examined some family variables in an under-research context and have enlarge the studies focus on the service sector.

With regards to the limitations of our study, firstly, we based our empirical analysis on secondary data sources. For this reason, we were unable to capture the managers' perceptions about the influence of different types of FF managers, their motivations and strategic objectives during international expansion, the level of professionalisation and how long the manager has been working at the company. The ability of the family managers to commit to internationalisation and enhance their performance may depend on their capability in gaining the consensus of the family owners (Graves \& Thomas, 2008).

Secondly, our study focuses on a single industry from a particular country, which means that the results cannot be extrapolated to other industries and countries. Future studies could include different industries or countries with the aim to compare the results obtain here and expand our knowledge of hotel chains and the influence of familiness on internationalisation and performance.

\section{References}

Abdellatif, M., Amann, B., \& Jaussaud, J. (2010). Family versus nonfamily business: A comparison of international strategies. Journal of Family Business Strategy, 1(2), 108-116. https://doi.org/10.1016/j. jfbs.2010.04.004

Alayo, M., Irrutalde, T., \& Maseda, A. (2021). Innovation and internationalization in family SMEs: analyzing the role of family involvement. European Journal of Innovation Management, in press, https://doi.org/10.1108/EJIM-07-2020-0302.

Alayo, M., Maseda, A., Iturralde, T., \& Arzubiaga, U. (2019). Internationalization and entrepreneurial orientation of family SMEs: The influence of the family character. International Business Review, 28(1), 48-59. https://doi.org/10.1016/j.ibusrev.2018.06.003

Anderson, R.C., \& Reeb, D. M. (2003). Founding family ownership and firm performance. Journal of Finance, 58(3), 1301-1329. https://doi. org/10.1111/1540-6261.00567

Andreu, R., Claver, E., Quer, D., \& Rienda, L. (2018). Family ownership and Spanish hotel chains: An analysis of their expansion through internationalization. Universia Business Review (continued as UCJC Business and Society Review), 59, 40-75. https://doi.org/10.3232/UBR.2018.V15.N3.02

Andreu, R., Claver, E., Quer, D., \& Rienda, L. (2020). Family involvement and Spanish hotel chains' entry modes abroad. Current Issues in Tourism, 23(11), 1375-1393. https://doi.org/10.1080/13683500.201 9.1620186

Aronoff, C. E. (1998). Megatrends in family business. Family Business Review, 11(3), 181-186. https:// doi.org/10.1111/j.1741-6248.1998.00181.x

Arregle, J. L., Duran, P., Hitt, M. A., \& van Essen, M. (2017). Why is family firms' internationalization unique? A meta-analysis. Entrepreneurship Theory and Practice, 41(5), 801-831. https://doi. org/10.1111/etap. 12246

Assaf, A. G., Josiassen, A., \& Oh, H. (2016). Internationalization and hotel performance: the missing pieces. Tourism Economics, 22(3), 572-592. https: / / doi.org/10.5367/te.2015.0460

Astrachan, J. H., \& Kolenko, T. A. (1994). A neglected factor explaining family business success: human resource practices. Family Business Review, 7(3), 251-262. https://doi.org/10.1111/j.17416248.1994.00251.x

Beck, L., Janssens, W., Debruyne, M., \& Lommelen, T. (2011). A study of the relationships between generation, market orientation, and innovation in family firms. Family Business Review, 24(3), 252272. https: //doi.org/10.1177/0894486511409210

Bobillo, A. M., Rodríguez-Sanz, J. A., \& TejerinaGaite, F. (2013). Shareholder activism and internationalization in the family firm. Journal of Business Economics and Management, 14(5), 867-885.

Boellis, A., Mariotti, S., Minichilli, A., \& Piscitello, L. (2016). Family involvement and firms' establishment mode choice in foreign markets. Journal of International Business Studies, 47(8), 929-950. https: / / doi.org/10.1057/jibs.2016.23

Brida, J. G., Driha, O., Ramón-Rodríguez, A. B., \& Scuderi, F. (2015). Dynamics of internationalisation of the hotel industry: the case of Spain. International Journal of Contemporary Hospitality Management, 27(5), 1024-1047. https://doi. org/10.1108/IJCHM-11-2013-0527

Brida, J. G., Ramón-Rodriguez, A. B., Such-Devesa, M. J., \& Driha, O. (2016). The inverted-U relationship between the degree of internationalization and the performance: the case of Spanish hotel chains. Tourism Management Perspectives, 17, 72-81. https: //doi.org/10.1016/j.tmp.2015.12.016

Buckley, P. J., \& Casson, M. (1976). The future of the multinational enterprise. London: MacMillan.

Calabrò, A., Campopiano, G., Basco, R., \& Pukall, T. (2017). Governance structure and internationalization of family-controlled firms: the mediating 
role of international entrepreneurial orientation. European Management Journal, 35(2), 238-248. https://doi.org/10.1016/j.emj.2016.04.007

Carr, C., \& Bateman, S. (2009). International strategy configurations of the world's top family firms. Management International Review, 49(6), 733-758. https://doi.org/10.1007/s11575-009-0018-3

Casillas, J. C., \& Acedo, F. J. (2005). Internationalisation of Spanish family SMEs: an analysis of family involvement. International Journal of Globalisation and Small Business, 1(2), 134-151. https:// doi.org/10.1504/IJGSB.2005.008010

Casillas, J. C., Moreno, A. M., Acedo, J. C., Gallego, M. A., \& Ramos, E. (2009). An integrative model of the role of knowledge in the internationalization process. Journal of World Business, 44(3), 311-322. https: / / doi.org/10.1016/j.jwb.2008.08.001

Caves, R. (1971). International corporations: the industrial economics of foreign investment. Economica, 38(149), 1-27.

Cerrato, D., \& Piva, M. C. (2012). The internationalization of small and medium-sized enterprises: the effect of family management, human capital and foreign ownership. Journal of Management \& Government, 16, 617-644. https://doi.org/10.1007/ s10997-010-9166-X

Chen, Y.-R., Huang, Y.-L., \& Chen, C.-N. (2009). Financing constraints, ownership control, and crossborder M\&As: evidence from nine East Asian economies. Corporate Governance: An International Review, 17(6), 665-680. https://doi.org/10.1111/ j.1467-8683.2009.00770.x

Chiu, D-F. (2015). The influences of formal and informal institutions on Taiwanese family-owned firms' entry mode choice. Advances in Economics and Business, 3(9), 383-359. https://doi.org/10.13189/ aeb.2015.030904

Chrisman, J. J., Chua, J. H., \& Litz, R. A. (2004). Comparing the agency cost of family and nonfamily firms: conceptual issues and exploratory evidence. Entrepreneurship Theory and Practice, 28(4), 335-354. https://doi.org/10.1111/j.15406520.2004.00049.x

Chua, J. H., Chrisman, J. J., \& Sharma, P. (1999). Defining family business by behavior. Entrepreneurship Theory and Practice, 23(4), 19-39. https:// doi.org/10.1177/104225879902300402

Chua, J. H., Chrisman, J. J., Steier, L. P., \& Rau, S. B. (2012). Sources of heterogeneity in family firms: an introduction. Entrepreneurship Theory and Practice, 36(6), 1103-1113. https://doi. org/10.1111/j.1540-6520.2012.00540.x

Claver, E., Rienda, L., \& Quer, D. (2007). The internationalisation process in family firms: choice of market entry strategies. Journal of General Management, 33(1), 1-16. https://doi. org/10.1177/030630700703300101

Claver, E., Rienda, L., \& Quer, D. (2008). Factores familiares y compromiso internacional: evidencia empírica en las empresas españolas. Cuadernos de Economía y Dirección de la Empresa, 11(35), 7-25. https://doi.org/10.1016/S1138-5758(11)70057-3

Claver, E., Rienda, L., \& Quer, D. (2009). Family firms' international commitment: The influence of familyrelated factors. Family Business Review, 22(2), 125135. https://doi.org/10.1177/0894486508330054
Contractor, F. J., \& Kundu, S. K. (1998). Modal choice in a world of alliances: analyzing organizational forms in the international hotel sector. Journal of International Business Studies, 29(2), 325-356. https: //doi.org/10.1057/palgrave.jibs.8490039

Cucculelli, M., Mannarino, L. Pupo, V., \& Ricotta, F. (2014). Owner-management, firm age, and productivity in Italian family firms. Journal of Small Business Management, 52(2), 325-343. https://doi. org/10.1111/jsbm. 12103

Davis, J. H., Schoorman, F. D., Mayer, R. C., \& Tan, H. H. (2000). The trusted general manager and business unit performance: empirical evidence of a competitive advantage. Strategic Management Journal, 21(5), 563-576. https://doi.org/10.1002/ (SICI) 1097-0266(200005) 21:5<563: : AID SMJ99>3.0.CO;2-0

De Massis, A., Frattini, F., Kotlar, J., Messeni-Petruzzelli, A., \& Wright, M. (2016). Innovation through tradition: lessons from innovative family businesses and directions for future research. Academy of Management Perspectives, 30(1), 93-116. https:// doi.org/10.5465/amp.2015.0017

Debicki, B. J., Miao, C., \& Quian, S. (2020). Internationalization and family firm performance. A crosscultural meta-analysis of the main effect and moderating factors. Cross Cultural \& Strategic Management, 27(1), 1-25. https://doi.org/10.1108/CCSM04-2019-0075

Elango, B. (2004). Geographic scope of operations by multinational companies: an exploratory study of regional and global strategies. European Management Journal, 22(4), 431-441. https://doi. org/10.1016/j.emj.2004.06.006

Faccio, M., Marchica, M-T., \& Mura, R. (2011). Large shareholder diversification and corporate risk-taking. The Review of Financial Studies, 24(11), 36013641. https://doi.org/10.1093/rfs/hhr065

Fernández, Z., \& Nieto, M. J. (2005). Internationalization strategy of small and medium-sized family businesses: some influential factors. Family Business Review, 18(1), 77-89. https://doi. org/10.1111/j.1741-6248.2005.00031.x

Fernández, Z., \& Nieto, M. J. (2006). Impact of ownership on the international involvement of SMEs. Journal of International Business Studies, 37, 340-351. https://doi.org/10.1057/palgrave. jibs. 8400196

Filatochev, I., Lien, Y. C., \& Piesse, J. (2005). Corporate governance and performance in publicly listed, family-controlled firms: evidence from Taiwan. Asia Pacific Journal of Management, 22, 257-283. https://doi.org/10.1007/s10490-005-3569-2

García de Soto, E., \& Vargas, A. (2015). Choice of entry mode, strategic flexibility and performance of international strategy in hotel chains: an approach based on real options. European Journal of Tourism Research, 9, 92-114.

Gómez-Mejía, L., Cruz, C., Berrone, P., \& De Castro, J. (2011). The bind that ties: socioemotional wealth preservation in family firms. Academy of Management Annals, 5(1), 653-707. https://doi.or $\mathrm{g} / 10.5465 / 19416520.2011 .593320$

Gómez-Mejía, L., Makri, M., \& Larraza-Kintana, M. (2010). Diversification decisions in family-controlled firms. Journal of Management Studies, 
47(2), 223-252. https://doi.org/10.1111/j.14676486.2009.00889.x

Granata, D., \& Chirico, F. (2010). Measures of value in acquisitions: family versus nonfamily firms. Family Business Review, 23(4), 341-354. https://doi. org/10.1177/0894486510386367

Grant, R. M., Jammine, A. P., \& Thomas, H. (1988). Diversity, diversification, and profitability among British manufacturing companies. Academy of Management Journal, 31(4), 771-801. https://doi. org/10.5465/256338

Graves, C., \& Shan, Y. C. (2014). An empirical analysis of the effect of internationalization on the performance of unlisted family and nonfamily firms in Australia. Family Business Review, 27(2), 142-160. https: / /doi.org/10.1177/0894486513491588

Graves, C., \& Thomas, J. (2004). Internationalisation of the family business: a longitudinal perspective. International Journal of Globalisation and Small Business, 1(1), 7-27. https://doi.org/10.1504/ IJGSB.2004.005615

Graves, C., \& Thomas, J. (2006). Internationalization of Australian family businesses: a managerial capabilities perspective. Family Business Review, 19(3), 207-224. https://doi.org/10.1111/j.17416248.2006.00066.x

Graves, C., \& Thomas, J. (2008). Determinants of the internationalization pathways of family firms: an examination of family influence. Family Business Review, 21(2), 151-167. https://doi.org/10.1111/ j.1741-6248.2008.00119.x

Hernánez-Perlines, F. (2018). Moderating effect of absorptive capacity on the entrepreneurial orientation of international performance of family businesses. Journal of Family Business Management, 8(1), 5874. https://doi.org/10.1108/JFBM-10-2017-0035

Hofstede, G. (1980). Culture's consequences. International differences in work-related values. Newbury Park-California: Sage Publications.

Kim, Y., \& Gao, F. Y. (2013). Does family involvement increase business performance? Family-longevity goals' moderating role in Chinese family firms. Journal of Business Research, 66(2), 265-274. https://doi.org/10.1016/j.jbusres.2012.08.018

Kraus, S., Mensching, H., Calabrò, A., Cheng, C-F., \& Filser, M. (2016). Family firm internationalization: a configurational approach. Journal of Business Research, 69(11), 5473-5478. https://doi. org/10.1016/j.jbusres.2016.04.158

Le Breton-Miller I., \& Miller D. (2013). Socioemotional wealth across the family firm life cycle: A commentary on "Family business survival and the role of boards." Entrepreneurship Theory and Practice, 37(6), 1391-1397. https://doi.org/10.1111/ etap. 12072

Lee, S., Upneja, A., Özdemir, Ö., \& Sun, K-A. (2014). A synergy effect of internationalization and firm size on performance. US hotel industry. International Journal of Contemporary Hospitality Management, 26(1), 35-49. https://doi.org/10.1108/ IJCHM-09-2012-0173

León-Darder, F., Villar-García, C., \& Pla-Barber, J. (2011). Entry mode choice in the internationalisation of the hotel industry: a holistic approach. The Service Industries Journal, 31(1), 107-122. https: / / doi.org/10.1080/02642069.2010.485198
Levy, H., \& Sarnat, M. (1970). International diversification of investment portfolios. The American Economic Review, 60(4), 668-675.

Liang, X., Wang, L., \& Cui, Z. (2014). Chinese private firms and internationalization: effects of family involvement in management and family ownership. Family Business Review, 27(2), 126-141. https:// doi.org/10.1177/0894486513480885

Lödhe, A. S. K., \& Calabrò, A. (2019). Understanding family firms' entry mode choices When going to China and India: an international opportunity identification-based approach. In Memili, E., \& Dibrell, C. (eds.) (2019). The Palgrave handbook of heterogeneity among family firms (pp. 847-872). Cham (Switzerland): Palgrave Mcmillan. https:// doi.org/10.1007/978-3-319-77676-7_31

Lu, J., Liang, X., Shan, M., \& Liang, X. (2015). Internationalization and performance of Chinese family firms: The moderating role of corporate governance. Management and Organization Review, 11(4), 645-678. https://doi.org/10.1017/mor.2015.32

Lu, J. W., \& Beamish, P. W. (2004). International diversification and firm performance: the S-curve hypothesis. Academy of Management Journal, 47(4), 598-609. https://doi.org/10.5465/20159604

Lu, Z., \& White, H. (2014). Robustness checks and robustness tests in applied economics. Journal of Econometrics, 178(1), 194-206. https://doi. org/10.1016/j.jeconom.2013.08.016

Luo, Y. (2002). Capability exploitation and building in a foreign market: implications for multinational enterprises. Organization Science, 13(1), 48-63. https://doi.org/10.1287/orsc.13.1.48.538

Mariotti, S., Marzano, R., \& Piscitello, L. (2021). The role of family firms' generational heterogeneity in the entry mode choice in foreign markets. Journal of Business Research, 132. https://doi. org/10.1016/j.jbusres.2020.10.064

Martorell, O., Mulet, C., \& Díez, D. (2016). Las empresas hoteleras y los apartamentos turísticos. In Aalen, E., \& Calero, F. (dir.). La actividad turística española en 2015 (pp. 55-69), Madrid: Síntesis.

Mazzi, C. (2011). Family business and financial performance: current state of knowledge and future research challenges. Journal of Family Business Strategy, 2(3), 166-181. https://doi.org/10.1016/j. jfbs.2011.07.001

Mensching, H., Calabrò, A., Eggers, F., \& Kraus, S. (2016). Internationalization of family and non-family firms: a conjoint experiment among CEOs. European Journal of International Management, 10(5), 581-604. https://doi.org/10.1504/ EJIM.2016.078795

Miller, D., \& Le Breton-Miller, I. (2006). Family governance and firm performance: agency, stewardship and capabilities. Family Business Review, 19(1), 73-87. https://doi.org/10.1111/j.17416248.2006.00063.x

Miller, D., Le Breton-Miller, I., \& Lester, R. H. (2010). Family ownership and acquisition behavior in publicly-traded companies. Strategic Management Journal, 31(2), 201-223. https://doi.org/10.1002/ smj.802

Miller, D., Le Breton-Miller, I., \& Lester, R. H. (2011). Family and lone founder ownership and strategic behaviour: social context, identity, and 
institutional logics. Journal of Management Studies, 48(1), 1-25. https://doi.org/10.1111/j.14676486.2009.00896.x

Miller, D., Le Breton-Miller, I., \& Scholnick, B. (2008). Stewardship vs. stagnation: an empirical comparison of small family and non-family businesses. Journal of Management Studies, 45(1), 51-78. https://doi.org/10.1111/j.1467-6486.2007.00718.x

Morck, R., Strangel, D. A., \& Yeung, B. (2000). Inherited wealth, corporate control and economic growth: the Canadian disease. In R. Morck (Ed.), Concentrated corporate Ownership (pp. 319-369). Chicago: University of Chicago Press. https://doi. org/10.7208/9780226536828-015

Navasivayam, K., Miao, L., \& Zao, X. (2007). An investigation on the relationship between compensation practices and firm performance in the US hotel industry. International Journal of Hospitality Management, 26(3), 574-587. https://doi. org/10.1016/j.ijhm.2006.05.001

Pearson, A. W., Carr, J. C., \& Shaw, J. C. (2008). Toward a theory of familiness: a social capital perspective. Entrepreneurship Theory and Practice, 32(6), 949-969. https://doi.org/10.1111/j.15406520.2008.00265.x

Peng, M. W., \& Jiang, Y. (2010). Institutions behind family ownership and control in large firms. Journal of Management Studies, 47(2), 253-273. https://doi.org/10.1111/j.1467-6486.2009.00890.x

Pla Barber, J., \& León Darder, F. (2004). La internacionalización de la industria hotelera española. Formas de entrada y factores determinantes. Papeles de Economía Española, 102, 193-206.

Plá-Barber, J., León-Darder, F., \& Villar, C. (2011). The internationalization of soft-services: entry modes and main determinants in the Spanish hotel industry. Service Business, 5, 139-154. https://doi. org/10.1007/s11628-011-0106-x

Pongelli, C., Carolli, M. G., \& Cucculelli, M. (2016). Family business going abroad: the effect of family ownership on foreign market entry mode decisions. Small Business Economics, 47, 787-801. https:// doi.org/10.1007/s11187-016-9763-4

Pukall, T. J., \& Calabrò, A. (2014). The internationalization of family firms: a critical review and integrative model. Family Business Review, 27(2), 103125. https: / / doi.org/10.1177/0894486513491423

Ramón, A. (2002). Determining factors in entry choice for international expansion. The case of the Spanish hotel industry. Tourism Management, 23(6), 597-607. https://doi.org/10.1016/S02615177(02)00024-9

Ray, S., Mondal, A., \& Ramachandran, K. (2018). How does family involvement affect a firm's internationalization? An investigation of Indian family firms. Global Strategy Journal, 8(1), 73-105. https://doi. org/10.1002/gsj.1196

Rienda, L., Claver, E., \& Andreu, R. (2020). Family involvement, internationalisation and performance: An empirical study of the Spanish hotel industry. Journal of Hospitality and Tourism Management, 42, 173-180. https://doi.org/10.1016/j. jhtm.2020.01.002

Rienda, L., Claver, E., \& Andreu, R. (2021). Internationalisation and family involvement: A Stewardship approach in the hotel industry. In Leppäaho,
T., \& Jack, S. (Eds): Handbook on family firm internationalisation (pp. 37-62), Palgrave McMillan. https://doi.org/10.1007/978-3-030-66737-5_2

Ruigrok, W., \& Wagner, H. (2003). Internationalization and performance: an organizational learning perspective. Management International Review, 43(1), 63-83.

Sainaghi, R. (2011). RevPAR determinants of individual hotels: evidences from Milan. International Journal of Contemporary Hospitality Management, 23(3), 297-311. https://doi. org/10.1108/09596111111122497

Schwartz, Z., Altin, M., \& Singal, M. (2017). Performance measures for strategic revenue management: RevPAR versus GOPPAR. Journal of Revenue and Pricing Management, 16, 357-375. https://doi. org/10.1057/rpm.2016.23

Sciacia, S., Mazolla, P., \& Kellermanns, F. W. (2014). Family management and profitability in private family-owned firms: Introducing generational stage and the socioemotional wealth perspective. Journal of Family Business Strategy, 5(2), 131-137. https: / /doi.org/10.1016/j.jfbs.2014.03.001

Sciacia, S., Mazzola, P., Astrachan, J. H., \& Pieper, T. M. (2012). The role of family ownership in international entrepreneurship: exploring nonlinear effects. Small Business Economics, 38, 15-31. https://doi.org/10.1007/s11187-010-9264-9

Segaro, E. L., Larimo, J., \& Jones, M. V. (2014). Internationalisation of family small and medium sized enterprises: the role of stewardship orientation, family commitment culture and top management team. International Business Review, 23(2), 381395. https://doi.org/10.1016/j.ibusrev.2013.06.004

Sonfield, M.C., \& Lussier, R. N. (2004). First-, second-, and third-generation family firms: a comparison. Family Business Review, 17(3), 189-202. https: / / doi.org/10.1111/j.1741-6248.2004.00013.x

Sraer, D., \& Thesmar, D. (2007). Performance and behavior of family firms: evidence from the French stock market. Journal of the European Economic Association, 5(4), 709-751. https://doi.org/10.1162/ JEEA.2007.5.4.709

Stieg, P., Cesinger, B., Apfelthaler, G., Kraus, S., \& Cheng, C. F. (2018). Antecedents of successful internationalization in family and non-family firms: how knowledge resources and collaboration intensity shape international performance. Journal of Small Business Strategy, 28(1), 14-27.

Strike, V. M., Berrone, P., Sapp, S. G., \& Congiu, L. (2015). A socioemotional wealth approach to CEO career horizons in family firms. Journal of Management Studies, 52(4), 555-583. https://doi. org/10.1111/joms.12123

Tallman, S., \& Li, J. (1996). Effects of international diversity and product diversity on the performance of multinational firms. Academy of Management Journal, 39(1), 179-196. https://doi. org/10.5465/256635

Tsao, S. M., \& Lien, W. H. (2013). Family management and internationalization: the impact on firm performance and innovation. Management International Review, 53, 189-213. https://doi.org/10.1007/ s11575-011-0125-9

Villalonga, B., \& Amit, R. (2006). How do family ownership, control and management affect firm value? 
Journal and Financial Economics, 80(2), 385-417. https://doi.org/10.1016/j.jfineco.2004.12.005

Wernerfelt, B. (1984). A resource-based view of the firm. Strategic Management Journal, 5(2), 171-180. https://doi.org/10.1002/smj.4250050207

Westhead, P., \& Howorth, C. (2006). Ownership and management issues associated with family firm performance and company objectives. Family Business Review, 19(4), 301-319. https://doi.org/10.1111/ j.1741-6248.2006.00077.x

Westhead, P., Howorth, C., \& Cowling, M. (2002). Ownership and management issues in first and multi-generation family firms. Entrepreneurship and Regional Development, 14(3), 247-269. https:// doi.org/10.1080/08985620110112088

Xiao, Q., O’Neill, J. W., \& Mattila, A. S. (2012). The role of hotel owners: the influence of corporate strategies on hotel performance. International Journal of Contemporary Hospitality Management, 24(1), 122139. https: //doi.org/10.1108/09596111211197836

Yamanoi, J., \& Asaba, S. (2018). The impact of family ownership on establishment and ownership modes in foreign direct investment: the moderating role of corruption in host countries. Global Strategy Journal, 8(1), 106-135. https://doi.org/10.1002/ gsj.1198

Zahra, S. A. (2005). Entrepreneurial risk taking in family firms. Family Business Review, 18(1), 23-40. https: / /doi.org/10.1111/j.1741-6248.2005.00028.x

Zahra, S. A. (2003). International expansion of U.S. manufacturing family businesses: the effect of ownership and involvement. Journal of Business Venturing, 18(4), 495-512. https://doi.org/10.1016/ S0883-9026(03)00057-0

Zahra, S. A., Hayton, J. C., Neubaum, D. O., Dibrell, C., \& Craig, J. (2008). Culture of family commitment and strategic flexibility: the moderating effect of stewardship. Entrepreneurship Theory and Practice, 32(6), 1035-1054. https://doi. org $/ 10.1111 / j .1540-6520.2008 .00271 . x$

Zellweger, T. M., Kellermanns, F. W., Chrisman, J. J., \& Chua, J. H. (2012). Family control and family firm valuation by family CEOs: the importance of intentions for transgenerational control. Organization Science, 23(3), 851-868. https://doi. org/10.1287/orsc. 1110.0665 